\title{
INDIAN BANKING INDUSTRY: A NEW EVIDENCE FROM A PROFITABILITY PERSPECTIVE
}

\author{
Shailendra RAI ${ }^{\circledR 1}$, Miia $\mathrm{CHABOT}^{2}$, Jean-Louis BERTRAND ${ }^{\circledR 2}$, Imlak SHAIKH ${ }^{\circledR} 1^{*}$ \\ ${ }^{1}$ Management Development Institute Gurgaon, Mehrauli Road, Sukhrali, 122007 Gurugram, India \\ ${ }^{2}$ ESSCA School of Management, Angers, Pays de la Loire, France
}

Received 17 June 2020; accepted 23 March 2021

\begin{abstract}
While India is set to become the world's most populous country by 2050, it is also the home to the world's largest number of unbanked individuals. This paper aims to investigate the profitability issue with a focus on public banks. Using a new methodology based on comparisons tests and panel analysis that test unobserved heterogeneities between banks. We show that public banks are not low performers, nor can private banks be considered high performers Finally, we show that the proportion of non-performing assets (NPAs) is a real concern and requires urgent attention of government and regulators for Indian banks to serve profitability their home market. Banks that make more profits on non-interest income are not necessarily less profitable than others. Further, outcomes favour the ideas that if public banks are able to clean-up their non-performing assets as well as follow a sound prudential regulation, their profits could strongly grow. Future reforms must consider the public bank's key role in the growth of the India's economic outlook, especially when it comes to projects of social importance and national priority. The study is based on 105 banks with cross-sections from 2003-2016; however, India's government has initiated reforms in the banking segment, which has led to a significant decrease in government stake and the number of banks.
\end{abstract}

Keywords: Indian banks, profitability, non-performing assets, net operating income, public banks, private banks.

JEL Classification: G21, C23, C52.

\section{Introduction}

Robust financial services can be strong drivers for Indian economic growth, both when they mobilize savings for productive use, but also when they efficiently allocate funds and help manage risks (Kapoor, 2014). As such, the banking segment plays a vital part in developmental process (Jayaraman \& Srinivasan, 2014).

This paper is motivated by the forthcoming required changes in the banking segment of India. While India is set to become the world's most populous country by 2050 , India is the nation with the largest number of unbanked individuals (e.g., Kapoor, 2014). The working population is young and expanding, but one hundred and forty-five million people still do not have a bank account. The Indian banking industry is projected to be third largest banking industry by the year 2025 (KPMG-CII, 2013). Despite this favorable environment, Indian banks are currently unable to keep pace. This can be partly explained by the highly regulated environment in which they are evolving (Jayaraman \& Srinivasan, 2014).
A large number of researches presents the functional competence of Indian banking system. These works help to identify the best practices and offer relevant benchmarks of the influence of policy measures on efficiency and performance of banks (Das \& Ghosh, 2006). On the other hand, the reforms of the latter half of the 2000s have not been widely studied. Throughout the existing literature, the main focus remains on the methodological cost effectiveness of economic establishments. a handful of pragmatic works are connected to revenue. Historically, empirical findings have suggested that structure of ownership play a prominent role in the bank's efficiency and performance (Fujii et al., 2014; Jayaraman \& Srinivasan, 2014).

This paper investigates the empirical discrepancies between private and public financial institutions in India. Ahamed (2017) proposed an analysis by pitting two groups of banks against each other. The arbitrary distinction between the groups was based on the quality of the assets they held, for example low quality assets versus high

*Corresponding author. E-mail: imlak.shaikh@mdi.ac.in 
quality assets. We propose a new approach using Return on Assets (ROA) as a criterion for ranking banks according to profitability. In our panel, the median ROA is $0.81 \%$. So, we have two groups of banks. "High ROA" consists of banks with ROA above $0.81 \%$ and "low ROA" consists of all banks with ROA below $0.81 \%$. We then perform mean comparison tests between the two groups.

We deepen the approach proposed by Pennathur et al. (2012), Jayaraman and Srinivasan (2014) and Banerjee and Velamuri (2015) in distinguishing net operational revenue, interest revenue as well as non interest revenue. We confirm the negative relationship between ROA and NPAs recently reported by Bawa et al. (2019). Our empirical approach enables us to further refine this finding. Step-by-step panel estimations give us an opportunity to discuss the way public banks can meet the challenges of declined profitability.

Three key results are obtained. First, we demonstrate that public banks cannot be associated to low-ROA profiles, nor can private banks be considered as high-ROA profiles. A second result shows that public banks hold several assets that should be better mobilized, and more particularly non-interest- income. A third result highlights the considerable influence played by non- performing assets in the ability of all type of banks to thrive. Our work considers 105 banks with cross-sections from 2003-2016, but recent Indian banking sector consolidation in public banks led to a reduction in banks' number. Further, the current federal decision of privatization of few public sector banks may lead to more restructuring of the Indian financial system; eventually, it may improve the operational efficiency of Indian banks. Hence, the results and findings reported here ex-post and can be further validated with enhanced data.

Section 1 presents a literature review in relation to banking sector and discusses the main findings related to the issue of performance. Section 2 presents the data, the empirical methodology, and the associated research questions. Section 3 introduces and discusses the results. Section "Conclusions" concludes with policy implications, and required measures to increase the profitability of Indian banks.

\section{Literature review}

\subsection{Literature on banking performance}

The effect of reforms on Indian banks' ability to increase their performance has been treated disparately in the literature. Numerous studies converge on the fact that amid 1986 and 1991, on average state owned banks were more well-organized than foreign and private banks (Patti \& Hardy, 2005; Das \& Ghosh, 2006), but depending on the period, this was not always true. When looking at the period (1992-1995), Sathye (2003) showed that public banks were not the only ones to enhance, on average, their efficiency levels. Foreign banks experienced a similar effect. More generally, attesting to a noteworthy increase in banking efficiency in the early phase of reforms is difficult (Sarkar \& Bhaumik, 1998). In addition, public sector banks do not adjust as y enthusiastically to the liberalization as private and foreign banks (Fujii et al., 2014).

While the banking sector, as a whole, showed significant progress in efficiency levels sometime after the reforms, the empirical literature highlights a decline in cost-efficiency after 1992 (Zhao et al., 2010). This can be attributed to the underutilization of resources and to the magnitude of operations that banks had to face at this juncture (Das \& Ghosh, 2006). And while Kumbhakar and Sarkar (2005) showed that income effectiveness of banks followed a decreasing pattern at this time, public sector banks exhibited lower cost-effectiveness than private and foreign banks.

The post-reform period of 2000-2004 is characterized by an increased competition between banking institutions (Prasad \& Ghosh, 2005). During this time, the risk in banks' productivity was largely driven by technological progress (Zhao et al., 2010; Casu et al., 2013). Deregulation has improved the banks' performance (Das \& Kumbhakar, 2012) and fostered competition in the lending market (Zhao et al., 2010).

The significance of struggle has been acknowledged by India's Central Bank (RBI). In theory, increased rivalry is supposed to boost efficiency without consideration to the banks' ownership structure (Zhao et al., 2010). The continuation of the profit hypothesis (Mueller, 1977) suggests that competition is a key driver for the long-term convergence of profits. Competitive pressure is therefore presented in the literature as the solution to levelling differences in terms of productive efficiency per status.

Unfortunately, this is not the case in India. Banks' ownership structures play an important chunk in the ability of Indian institutions to perform. While the last few years have been characterized by an enhanced interconnection between government-owned and -operated banks, no inter-ownership convergence has been observed (Patti \& Hardy, 2005). Strong dissimilarities persist between banks as dissimilar proprietorship structures respond to fluctuations in the regulatory setting at different speeds.

This does not come as a surprise, as numerous empirical studies have shown that private or foreign banks generally perform better than public banks (Casu et al., 2013; Ammar \& Boughrara, 2019). But, in the case of India, some specificities are worth noting. The relationship between ownership and banking performance must indeed be examined with reference to the deregulation process initiated in the 1990s. Studies ranking the efficiency levels per status just before the second phase of reforms initiated by the Narasimham Committee II demonstrated that Public banks increased their performance (Sarkar \& Bhaumik, 1998; Sarkar et al., 1998; Bhaumik \& Dimova, 2004). The divergences between Indian banks narrowed after these reforms. However, this narrowing has not persisted in the long term (Fujii et al., 2014).

Thus, it emerges that the issue of performance in the banking industry cannot be approached as broadly as the 
literature suggests. When examining the internal abilities (i.e. functional efficiency) of banks to thrive, a distinction must be made between the concepts of productivity and profitability. In practice, this means that banks must be ranked by examining their revenues (Sahoo \& Tone, 2009; Tabak \& Tecles, 2010), cost efficiencies (Sensarma, 2008; Tabak \& Tecles, 2010; Tamatam et al., 2019; Vera-Gilces et al., 2020) and technical efficiencies (Das \& Ghosh, 2006; Cruz-García et al., 2020). This is not only a question of terminology. These concepts differ from one bank to another, as governance modes obviously differ per status. The bank's technical efficiency refers to its performance, i.e., success or failure, in transforming inputs into outputs (Das \& Ghosh, 2006). Practical competence was formerly established for practice in a non-market setting where amounts are not available, or consistent. On the cost effectiveness side, variances in normal costs have been studied by approximating parsimonies of scale and, to a slighter degree, of scope. The majority of these studies agree on the fact that ownership structures affect the ability of Indian banks to perform. There is however, a lack of research on the determinants of profitability per ownership status (Ray \& Das, 2010; Bongini et al., 2019). In this field of investigation, the quality of bank assets is of primary concern (Fujii et al., 2014). Firstly, because this remains a topic of some importance in India. But, also, because when they are introduced into models of bank performance (Park \& Weber, 2006), non-performing assets offer additional information for strategic decision-making. This is of the utmost importance for managers and regulators in India, since these assets affect bank profitability (Bawa et al., 2019; Chen et al., 2019).

\subsection{Market review}

Even before its political independence in 1947, India was the largest country in South Asia with a well-developed banking sector (Sathye, 2003). At that period, a large volume of foreign and domestic banks was present and the stock market was well organized. The industry, which enjoyed free and relatively liberal banking till the 1950s experienced a reversal in the subsequent quasi of the 1960s and initial half of the 1970s when the government began nationalizing the banks (see Figure 1).
This social agenda, measured as to geographical and sectoral coverage is widely presented as a success, as the state owned banks have additional 55,000 branches to their network. In reality, the Indian banking sector of the time was in distress: the vast majority of assets were managed by public sector banks, interest rate controls were administered and syndicated lending was mandatory (Bhaumik \& Piesse, 2008).

It became clear in the 1980s that, in profitability and service quality, national banks could not contest with foreign and private banks. The banking sector was severely restrained through stringent entrance controls, interest rate controls and reserve supplies, amongst other constraints. Banks were operating in non-financially viable areas and were situated in areas of political importance.

The central bank consequently started a reorganisation of the banking segment, based on the endorsements of the Narasimham Commission I and II (Narasimham et al., 1991; Sarkar \& Bhaumik, 1998; Sarkar et al., 1998; Fujii et al., 2014). Consequently, industry concentration declined during the early 2000s, and the cost of financial intermediation has declined. These measures made for a competitive environment, but the profitability of public banks declined considerably during this period. That being so, interest spreads narrowed to match international standards. One of the most significant recommendations was the formation of ARC (e.g., the IARC, acting under the SARFAESI Act, 2002), first intended to clean the banks' balance sheets, but also to help the recovery of non-performing loans.

From 2005 to 2007, an accommodating monetary policy accompanied a favorable macroeconomic environment. However, just before the sub-prime crisis, the continued high credit demand began to weigh on Indian banks. The banking sector could not keep pace, and the cost of borrowings increased, leading to the flight of deposits and interbank borrowings towards public banks. Depositors also moved their fiscal reserves from overseas and private banks to state owned and controlled banks. Indian national banks marginalized the activities of private sector banks. This led to inefficient credit allocations and to a worsening of their financial statement. A considerable increase in substandard loans affected the profitability of government -owned and -operated banks.

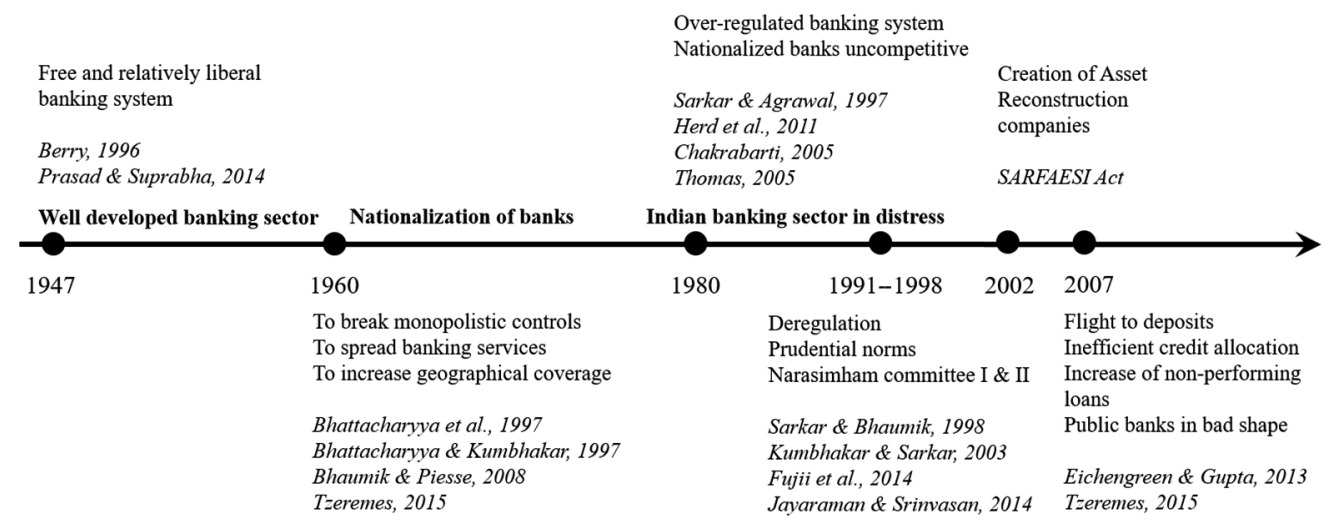

Figure 1. The reforms in the Indian banking sector (source: authors' compilation) 


\section{Methodology and data}

The first step of our analysis aims at investigating the main differences between private and public Indian banks. For this, two representative profiles have been constructed. One gathers low-ROA banks while the other one deals with high-ROA banks. Detailed comparisons and tests are provided. The second step is devoted to the estimation of a model for which we control for unobserved heterogeneities between banks, by using random effects and fixed effects estimators.

Our database contains 105 banks, which, to our knowledge, is a larger database than any other database used in previous research (Das \& Ghosh, 2006; Bhaumik \& Piesse, 2008; Pennathur et al., 2012; Jayaraman \& Srinivasan, 2014; Banerjee \& Velamuri, 2015; Bawa et al., 2019). We collected data for 27 public institutions (both state and nationalised), 34 private banks and 44 overseas banks functioning in India. Our analysis covers the year 2003-2016 ${ }^{1}$. The last step of our analysis investigates the potential discrepancies with the banks in which foreign shareholders hold at least 50\%. The data was sourced from the central bank's website, Bankscope (Orbis) and Bloomberg. Our study of banking profitability in the Indian banking segment is based on the following model:

$$
R O A_{i t}=\alpha\left(x_{i}\right) t+\beta\left(y_{i}\right) t+\epsilon_{i t},
$$

where: ROAi represents the Return On Assets of bank(i). $x i$ is a factor gathering banks (i) balance sheets elements: total_equity, total_ssets, total_deposits, total_loans, interbank_assets, non-performing assets, loan-loss provisions, tier one, net operating income. $y i$ is composed of financial market information: bank returns and Bloomberg one year forward default probability. $\epsilon_{t}$ is the white noise term. The factors engaged in Equation 1 are enumerated in Table 1. Once stationarity is confirmed, we use Panel OLS to estimate several variants of Equation 1. The significance of FE (fixed-effects) compared to RE (randomeffects) is confirmed with Hausman test assessments. In our regressions, stipulations under fixed-effects have generally been the furthermost suitable ones.

\section{Research hypotheses}

We formulate the following hypotheses: 1 . Public banks cannot be associated to low-ROA profiles 2 . Private banks cannot be associated to high-ROA profiles 3 . Public banks benefit from their Net Operating Income 4. Private banks suffer from limitations on their activity.

\section{Results}

\subsection{Descriptive statistics}

Table 2 allows to get a first picture of the discrepancies between Indian banks on the basis of several balance sheets

\footnotetext{
1 Ahamed (2017) gathers a sample that focuses only on Indian commercial banks on a period that covers the years 1998 to 2014 .
}

Table 1. List of variables

\begin{tabular}{|c|c|c|}
\hline Variable & Variables employed & Relevant studies \\
\hline$R O A i$ & $\begin{array}{l}\text { Profitability, Return on } \\
\text { Assets }\end{array}$ & $\begin{array}{l}\text { Sahoo and Tone }(2009) \\
\text { Tabak and Tecles }(2010) \\
\text { Das and Kumbhakar } \\
(2012) \\
\text { Gulati and Kumar } \\
(2016)\end{array}$ \\
\hline $\begin{array}{l}(x i) \\
\text { Balance } \\
\text { Sheets }\end{array}$ & $\begin{array}{l}\text { Total_Assets (TA) } \\
\text { Total_Deposits (D) } \\
\text { Interbank_Assets (ITB) } \\
\text { Total_Loans (TL) } \\
\text { Non-Perf. Assets (NPA) } \\
\text { Loan Loss Provisions } \\
\text { (LLP) } \\
\text { Tier One (T1) }\end{array}$ & $\begin{array}{l}\text { Das and Ghosh (2006) } \\
\text { Bhaumik and Piesse } \\
(2008) \\
\text { Pennathur et al. (2012) } \\
\text { Jayaraman and } \\
\text { Srinivasan (2014) } \\
\text { Banerjee and Velamuri } \\
(2015)\end{array}$ \\
\hline Income & $\begin{array}{l}\text { Net Operating Income } \\
\text { (NOI) } \\
\text { Non Interest Income } \\
\text { (NII) } \\
\text { Interest Income (II) }\end{array}$ & $\begin{array}{l}\text { Gulati and Kumar (2016) } \\
\text { Ahamed (2017) }\end{array}$ \\
\hline $\begin{array}{l}(y i) \\
\text { Finacial } \\
\text { Markets }\end{array}$ & $\begin{array}{l}\text { Bank Returns (BkR) } \\
1 \text { Y. fwd Default } \\
\text { Probability (DP) }\end{array}$ & $\begin{array}{l}\text { Altman and Sabato } \\
(2005) \\
\text { Altman et al. (2010) }\end{array}$ \\
\hline
\end{tabular}

items over the period 2003-2016. In this table, the first group gathers all the banks, regardless of their ownership structures or ROA levels. The last decomposition proposed in this table sorts the banks on the basis of their average ROA over the period 2003-2016. Banks in the high-ROA group exhibited a return on asset higher than one percent over the study period, while banks in the low-ROA group were below the one-percent threshold. Two main results emerge from this table. Public banks remain the ones with the highest amounts of assets (TA), deposits (D) and loans (TL). This makes mechanically their tier one (T1) and loan loss provisions (LLP) bigger than in the other groups. These banks also carry stronger levels of risks. The amount of non-performing assets (NPA) is one of the first elements to be highlighted, however the volatility of the ROA is not negligible. Then, associated to private banks, the minimum sum of interbank assets in the public cohort is negative. Such a result implies that interbank defaults are already affecting the activity of some public banks. For their part, private banks exhibit the highest levels of performance (ROA) and are less exposed to risks (NPA, ITB). They also have a more limited importance in the economy (TA), while holding lower amounts of deposits (D) and loans (TL).

These first results tend to validate the assumption that public institutions are performing at a lower level than private banks. Yet, the last decomposition provided in this table shows quite a different picture. If public banks hold smaller levels of profitability (ROA) than in the private sector, they still perform better than the weakest ones (low-ROA group). In addition, private banks do not reach the highest performing levels. Their ROA remains well below high-ROA profiles, and they gather lower amounts of assets (TA), deposits (D), and loans (TL). It would be 
Table 2. Summary statistics in relation to balance sheets indicators (source: Reserve Bank of India, Bankscope (Orbis) and Bloomberg)

\begin{tabular}{|c|c|c|c|c|c|c|c|c|}
\hline & $R O A$ & $T A$ & $D$ & $I T B$ & $T L$ & $N P A$ & $L L P$ & $T 1$ \\
\hline \multicolumn{9}{|l|}{ 1.All Banks } \\
\hline Mean & 0.725926 & 1772960. & 1428208. & 65924.50 & 1047243. & 45384.13 & 1.214791 & 165614.7 \\
\hline Median & 0.814300 & 786128.1 & 709651.7 & 13171.26 & 460238.6 & 8355.850 & 0.970400 & 70120.00 \\
\hline Maximum & 4.962500 & 34451216 & 25998107 & 1301999. & 19783966 & 1791666 & 6.780100 & 2014879 \\
\hline Minimum & -7.119300 & 14746.34 & 10607.81 & -11805.77 & 6170.742 & 0.047200 & -2.381300 & 2600.000 \\
\hline Std. Dev. & 0.980386 & 3349195. & 2576162 . & 152912.8 & 2073303. & 129072.4 & 0.993676 & 273265.4 \\
\hline \multicolumn{9}{|c|}{ 2.Private Banks } \\
\hline Mean & 0.860459 & 1003959. & 713900.0 & 30523.54 & 570641.4 & 13788.24 & 0.984231 & 129173.2 \\
\hline Median & 0.946700 & 247054.4 & 210212.0 & 5128.291 & 155734.4 & 2385.700 & 0.742950 & 38498.31 \\
\hline Maximum & 4.962500 & 9860427. & 6357015 & 485996.1 & 5895227. & 293216.0 & 6.780100 & 818293.0 \\
\hline Minimum & -3.591300 & 14746.34 & 10607.81 & 52.00000 & 6170.742 & 0.194500 & -2.381300 & 4002.600 \\
\hline Std. Dev. & 0.987197 & 1840373. & 1145271. & 65891.19 & 1058919. & 37983.35 & 0.995805 & 197070.6 \\
\hline \multicolumn{9}{|c|}{ 3.Public Banks } \\
\hline Mean & 0.334311 & 2847573. & 2262756. & 109935.5 & 1712891. & 94122.39 & 1.376917 & 214263.9 \\
\hline Median & 0.550950 & 1511866. & 1262816. & 27309.54 & 832229.8 & 35916.25 & 1.190800 & 114171.9 \\
\hline Maximum & 0.988600 & 34451216 & 25998107 & 1301999. & 19783966 & 1791666. & 4.550500 & 2014879. \\
\hline Minimum & -7.119300 & 221602.4 & 141469.9 & -11805.77 & 94117.89 & 0.193900 & -0.465800 & 2600.000 \\
\hline Std. Dev. & 1.016431 & 4688703. & 3580224. & 218120.6 & 2935222. & 191251.0 & 0.961969 & 343061.2 \\
\hline \multicolumn{9}{|c|}{ 4.High-ROA Profiles } \\
\hline Mean & 1.428408 & 1433085. & 1075544. & 50260.28 & 823843.7 & 16915.60 & 1.123354 & 175207.7 \\
\hline Median & 1.341700 & 648039.3 & 589875.3 & 15499.10 & 387289.9 & 4852.300 & 0.785450 & 92548.65 \\
\hline Maximum & 4.962500 & 9860427. & 6357015. & 485996.1 & 5895227. & 293216.0 & 4.419000 & 818293.0 \\
\hline Minimum & 1.003300 & 17092.38 & 12253.20 & 15.10000 & 6991.899 & 0.047200 & -0.295500 & 4490.085 \\
\hline Std. Dev. & 0.422414 & 1895443. & 1216626. & 84268.32 & 1098748. & 38090.45 & 0.877264 & 207905.6 \\
\hline \multicolumn{9}{|c|}{ 5.Low-ROA Profiles } \\
\hline Mean & 0.296016 & 2015847. & 1672793. & 76858.46 & 1206518. & 63583.48 & 1.270635 & 162965.0 \\
\hline Median & 0.551400 & 908769.7 & 839240.7 & 11051.33 & 553306.4 & 14606.00 & 0.980650 & 64551.30 \\
\hline Maximum & 0.998100 & 34451216 & 25998107 & 1301999. & 19783966 & 1791666. & 6.780100 & 2014879. \\
\hline Minimum & -7.119300 & 24447.97 & 19416.86 & -11805.77 & 8916.815 & 0.129100 & -2.381300 & 2600.000 \\
\hline Std. Dev. & 0.976671 & 4010186. & 3135378. & 183942.0 & 2499483. & 159597.2 & 1.056029 & 300277.6 \\
\hline
\end{tabular}

Table 3. Summary statistics in relation to income indicators (source: Reserve Bank of India, Bankscope (Orbis) and Bloomberg)

\begin{tabular}{|l|c|c|c|c|c|c|}
\hline \multirow{2}{*}{} & \multicolumn{3}{|c|}{ High-ROA Profiles } & \multicolumn{3}{c|}{ Private Banks } \\
\cline { 2 - 7 } & NOI & NII & II & NOI & NII \\
\hline Mean & 29936.14 & 24324.92 & 77879.56 & 21790.62 & 20985.98 & 56026.03 \\
\hline Median & 12043.79 & 7754.576 & 38053.22 & 4588.004 & 3932.139 & 14197.66 \\
\hline Maximum & 270637.2 & 242816.4 & 573198.0 & 270637.2 & 258967.9 & 573198.0 \\
\hline Minimum & 595.4471 & 132.5770 & 1061.489 & -2319.489 & -196.5830 & 833.2280 \\
\hline Std. Dev. & 43376.36 & 37045.79 & 101849.7 & 42471.19 & 41829.35 & 99217.02 \\
\hline & & & & \multicolumn{2}{|c|}{ Public Banks } \\
\cline { 2 - 8 } & NOW-ROA Profiles & NII & II & NOI & \multicolumn{2}{|c|}{ NII } \\
\hline Mean & 34097.18 & 25963.16 & 114777.3 & 45590.82 & 34657.65 & 162736.8 \\
\hline Median & 13166.25 & 7702.362 & 55053.90 & 23838.17 & 12381.43 & 92378.14 \\
\hline Maximum & 663578.3 & 664671.5 & 1662461. & 663578.3 & 664671.5 & 1662461. \\
\hline Minimum & -2319.489 & -196.5830 & -42481.70 & -2172.738 & 547.6000 & -42481.70 \\
\hline Std. Dev. & 75531.60 & 72224.09 & 220234.8 & 87172.13 & 84478.47 & 257038.0 \\
\hline
\end{tabular}


therefore be too restrictive and simplistic to characterize public banks and private banks as low performers and high performers respectively. Public banks are meant to support the financing needs of the Indian economy on a structural basis. Throughout the different reforms, public banks have been encouraged to operate on riskier projects even in isolated regions. While the government can act as a guarantee for public banks when necessary, the fact that these banks are encouraged to act as policy implementers impacts their ability to generate profits. Public banks however outperform private banks and high-ROA profiles in terms of net operating income (Table 3). If the amount of interest revenue of national banks does not reach to the close of income generated by private banks, public banks exhibit however strong levels of non-interest income.

The next table (Table 4) shows that the one-year-forward probability of default (DP) is among the highest in relation to national banks. The biggest issue aimed at public banks is the amount of risks they carry over time. Their average bank return (BR) on the financial markets remains also well below the average performance of high-ROAs profiles and private banks.

\subsection{Mean comparisons tests}

The results discussed in the previous section (Table 2, 3, 4) and the mean- comparison tests provided in Table 5 confirm the relevance of assumptions 1 and 2 (see section 2). In all of the statistical tests realized, the null hypothesis is rejected. It is therefore not possible to describe public banks as banks with a low ROA profile and private banks as banks with a high ROA profile. If we focus the analysis on differences with respect to ROA, the biggest difference concerns public banks. This result confirms their inability to generate sufficient profits while they hold the biggest amounts of assets and deposits in the financial market. Public banks however hold very small differences with
high-ROA profiles in terms of other revenue and core income. Ahamed (2017) showed that low asset quality banks produce significantly more other revenue associated to high asset quality banks. The author also shows that public banks hold more low quality assets than private banks. Yet, while Ahamed (2017) concludes that low-quality asset banks, in other words, public banks underperform private banks, our results show otherwise. In fact, we show that public banks are closer to banks with a high ROA profile than private banks. Banks that make more profits on non-interest income are not necessarily less profitable than others (e.g., Bawa et al., 2019; Chen et al., 2019).

\subsection{Regression results and discussion}

In the panel data analysis (Tables 6 and 7), the net operating income (NOI) is a highly relevant variable that affects ROA positively (models 3 to 12). Total assets (TA) also constitute a possible source of profits (models 1 to 3). However, non-performing assets are highly significant and have a negative effect (models 8 to 12), smiler to the proportion of bad asset provisions (models 9 to 12). Interbank assets and total deposits do not either enter positively in the regressions (models 4 to 8 ). Finally, in model (11), the default probability of Indian banks affects their ability to generate profits.

While these first figures confirm the concerns towards Indian banks soundness, important differences between public and private banks can be stressed.

In Tables 8 and 9, the ROA of Public banks is positively associated to their net operating income (NOI). If public banks cannot be associated to high- ROA profiles in India, they still benefit from important sources of revenue. We verify the relevance of assumption 3 (section 2). However, interbank assets (ITB) and total deposits (D) negatively affect their ability to generate profits, and pubic banks are also affected by the size of their non-performing

Table 4. Summary statistics in relation to return on asset (source: Reserve Bank of India, Bankscope (Orbis) and Bloomberg)

\begin{tabular}{|c|c|c|c|c|c|}
\hline \multicolumn{3}{|c|}{ High-ROA Banks } & \multicolumn{3}{|c|}{ Private Banks } \\
\hline & $B R$ & $D P$ & & $B R$ & $D P$ \\
\hline Mean & 220.3267 & 0.001132 & Mean & 176.1576 & 0.001297 \\
\hline Median & 119.9000 & 0.000999 & Median & 85.92000 & 0.000991 \\
\hline Maximum & 1206.200 & 0.003820 & Maximum & 1206.200 & 0.006972 \\
\hline Minimum & 12.55000 & 0.000120 & Minimum & 6.840000 & 0.000120 \\
\hline Std. Dev. & 251.6792 & 0.000704 & Std. Dev. & 225.6806 & 0.001110 \\
\hline \multicolumn{3}{|c|}{ Low-ROA Banks } & \multicolumn{3}{|c|}{ Public Banks } \\
\hline & $B R$ & $D P$ & & $B R$ & $D P$ \\
\hline Mean & 144.2075 & 0.003412 & Mean & 158.7110 & 0.003309 \\
\hline Median & 91.92000 & 0.001889 & Median & 105.3400 & 0.001719 \\
\hline Maximum & 685.0200 & 0.123361 & Maximum & 790.3800 & 0.123361 \\
\hline Minimum & 6.840000 & 0.000454 & Minimum & 19.95000 & 0.000433 \\
\hline Std. Dev. & 139.9981 & 0.008550 & Std. Dev. & 149.4830 & 0.008597 \\
\hline
\end{tabular}


Table 5. Mean Comparison tests

\begin{tabular}{|c|c|c|c|c|c|c|}
\hline & \multicolumn{2}{|c|}{$R O A$} & \multicolumn{2}{|c|}{$T A$} & \multicolumn{2}{|c|}{$D$} \\
\hline & Difference & t-stat & Difference & t-stat & Difference & t-stat \\
\hline State \& Private Banks & 0.869 & 12.664 & 1017065.91 & 8.042 & 732076.104 & 8.242 \\
\hline Private Banks \& High-ROA Banks & 0.829 & 10.53 & 1100217.977 & 7.518 & 801349.935 & 7.813 \\
\hline State Banks \& High-ROA Banks & 1.436 & 45.728 & 1858467.051 & 16.722 & 1514847.183 & 15.821 \\
\hline Private Banks \& Low-ROA Banks & 0.860 & 12.660 & 1003958.534 & 8.0359 & 768480.112 & 7.975 \\
\hline \multirow[t]{2}{*}{ State Banks \& Low-ROA Banks } & 0.302 & 5.170 & 2370029.662 & 10.0889 & 1972902.379 & 9.615 \\
\hline & \multicolumn{2}{|c|}{$I T B$} & \multicolumn{2}{|c|}{ NOI } & \multicolumn{2}{|c|}{ NII } \\
\hline State \& Private Banks & 30909.591 & 6.822 & 24893.194 & 5.810 & 21269.327 & 7.398 \\
\hline Private Banks \& High-ROA Banks & 33579.175 & 6.416 & 28147.732 & 5.731 & 25269.486 & 9.021 \\
\hline State Banks \& High-ROA Banks & 84898.504 & 5.961 & 34151.096 & 12.235 & 17183.539 & 16.897 \\
\hline Private Banks \& Low-ROA Banks & 30657.389 & 6.825 & 20586.899 & 5.363 & 20985.981 & 7.390 \\
\hline \multirow[t]{2}{*}{ State Banks \& Low-ROA Banks } & 93558.614 & 8.434 & 47214.313 & 6.864 & 28404.555 & 6.810 \\
\hline & \multicolumn{2}{|c|}{ II } & \multicolumn{2}{|c|}{$T L$} & \multicolumn{2}{|c|}{$N P A$} \\
\hline State \& Private Banks & 57175.110 & 8.316 & 578100.035 & 7.944 & 14909.200 & 5.252 \\
\hline Private Banks \& High-ROA Banks & 80202.959 & 10.416 & 629350.297 & 7.488 & 16765.161 & 5.149 \\
\hline State Banks \& High-ROA Banks & 105978.439 & 16.661 & 1089342.757 & 15.595 & 54815.142 & 8.486 \\
\hline Private Banks \& Low-ROA Banks & 56358.655 & 8.296 & 570641.409 & 7.938 & 14350.865 & 5.225 \\
\hline \multirow[t]{2}{*}{ State Banks \& Low-ROA Banks } & 115035.544 & 9.215 & 1209609.904 & 8.565 & 14350.865 & 5.225 \\
\hline & \multicolumn{2}{|c|}{$L L P$} & \multicolumn{2}{|c|}{$B R$} & \multicolumn{2}{|c|}{$D P$} \\
\hline State \& Private Banks & 0.951 & 13.229 & 181.533 & 11.180 & 0.001 & 14.670 \\
\hline Private Banks \& High-ROA Banks & 1.0143 & 13.363 & 142.527 & 9.925 & 0.001 & 13.83 \\
\hline State Banks \& High-ROA Banks & 1.383 & 17.256 & 124.932 & 16.542 & 0.002 & 7.074 \\
\hline Private Banks \& Low-ROA Banks & 1.317 & 15.662 & 166.916 & 10.406 & 0.0012 & 14.888 \\
\hline State Banks \& Low-ROA Banks & 1.3777 & 22.814 & 156.854 & 17.241 & 0.0034 & 5.920 \\
\hline
\end{tabular}

Table 6. All Banks (State \& Private), Part I

\begin{tabular}{|c|c|c|c|c|c|c|}
\hline \multirow[t]{2}{*}{ Variable } & \multicolumn{6}{|c|}{ Regression model with sub-models } \\
\hline & (1) & $(2)$ & (3) & (4) & (5) & (6) \\
\hline$T A$ & $7.55^{\star * *}$ & $5.03^{\star * *}$ & $5.12^{* * *}$ & 1.70 & 1.59 & 1.43 \\
\hline$D$ & - & $-7.88^{\star * *}$ & $-7.78^{\star \star \star}$ & $-4.53^{\star * *}$ & $-4.77^{\star * *}$ & $-4.78^{\star * *}$ \\
\hline ITB & - & - & -4.83 & $-6.60^{* *}$ & $-5.94^{* *}$ & $-6.08^{\star *}$ \\
\hline NOI & - & - & - & $5.80^{\star *}$ & $5.13^{* *}$ & $5.26^{* *}$ \\
\hline$T L$ & - & - & - & - & - & - \\
\hline NPA & - & - & - & - & - & - \\
\hline$L L P$ & - & - & - & - & - & - \\
\hline$B R$ & - & - & - & - & - & - \\
\hline$D P$ & - & - & - & - & - & - \\
\hline$T 1$ & - & - & - & - & - & - \\
\hline Constant & $0.86^{\star \star *}$ & $0.89^{\star \star \star}$ & $0.90^{* * *}$ & $1.02^{\star * *}$ & $1.02^{* * *}$ & $1.02^{* * *}$ \\
\hline Obs & 1364 & 1225 & 1225 & 968 & 968 & 967 \\
\hline R-squared & 0.397282 & 0.411541 & 0.413543 & 0.583481 & 0.585481 & 0.586357 \\
\hline $\mathrm{Nb}$ of Banks & 105 & 104 & 104 & 104 & 104 & 104 \\
\hline$H-\operatorname{stat}(p$-value $)$ & 0.0164 & 0.0203 & 0.0546 & 0.002 & 0.0001 & 0.0000 \\
\hline
\end{tabular}


assets (NPA). This is further confirmed by the fact that an increase in their default probability (DP) reduces their ROA. In model 12, the tier one capital ratio (T1, Table 9) has a positive impact. These outcomes favor the ideas that if public banks are able to clean-up their non-performing assets as well as follow a sound prudential regulation, their profits could strongly grow (e.g., Bawa et al., 2019).

A noteworthy portion of liability in India is allocated by companies with comparatively inhibited refund capacities. And while it is problematic to measure the detailed exposure of banks in India, their capacity to absorb losses and to continue providing liquidity is questionable. As public banks hold a great sum of bad credits and consequently engage in higher capital charges, they may pursue to counterbalance this by indicting a complex interest rate on new advances (Sathye, 2003).

While there is obviously a need to overhaul the functioning of the public banks, a first solution for the central bank could be to support the banks in the setting of their net interest margins. It is perhaps a first way to meet the challenge of low profitability. Then, while supporting the public banks in cleaning up their assets, a smooth transition

Table 7. All Banks (State \& Private), Part II

\begin{tabular}{|c|c|c|c|c|c|c|}
\hline \multirow{2}{*}{ Variable } & \multicolumn{6}{|c|}{ Regression model with sub-models } \\
\hline & (7) & $(8)$ & (9) & $(10)$ & $(11)$ & $(12)$ \\
\hline$T A$ & 4.72 & 1.15 & 1.71 & 1.61 & 1.80 & 1.94 \\
\hline$D$ & $-4.86^{\star * *}$ & -1.55 & -5.95 & -7.91 & -1.14 & -2.10 \\
\hline$I T B$ & $-5.85^{\star *}$ & $-6.39^{* *}$ & -2.66 & -2.43 & -2.25 & -2.76 \\
\hline NOI & $5.32^{\star *}$ & $9.07^{* * *}$ & $1.31^{\star * *}$ & $1.33^{* * *}$ & $1.17^{\star * *}$ & $1.04^{* * *}$ \\
\hline$T L$ & $4.53^{\star * *}$ & 2.51 & 2.41 & 2.29 & 2.46 & 1.91 \\
\hline NPA & - & $-3.33^{\star * *}$ & $-2.44^{* * *}$ & $-2.52^{\star * *}$ & $-1.74^{\star * *}$ & $-1.42^{*}$ \\
\hline$L L P$ & - & - & $-0.21^{\star * *}$ & $-0.22^{* * *}$ & $-0.20^{\star * *}$ & $-0.41^{\star * *}$ \\
\hline$B R$ & - & - & - & -0.1 & -0.1 & -0.1 \\
\hline$D P$ & - & - & - & - & $-28.13^{* * *}$ & -7.68 \\
\hline$T 1$ & - & - & - & - & & 3.65 \\
\hline Constant & $1.06^{* * *}$ & $0.91^{\star \star \star}$ & $1.21^{\star * *}$ & $1.26^{\star * *}$ & $1.33^{\star * *}$ & $1.47^{\star \star \star}$ \\
\hline Obs & 967 & 921 & 889 & 871 & 862 & 742 \\
\hline R-squared & 0.595319 & 0.660796 & 0.715274 & 0.712171 & 0.732326 & 0.858719 \\
\hline $\mathrm{Nb}$ of Banks & 104 & 104 & 103 & 101 & 100 & 87 \\
\hline$H-\operatorname{stat}(p$-value $)$ & 0.0000 & 0.0015 & 0.0037 & 0.0036 & 0.0079 & 0.0951 \\
\hline
\end{tabular}

Table 8. State Banks, Part I

\begin{tabular}{|c|c|c|c|c|c|c|}
\hline \multirow{2}{*}{ Variable } & \multicolumn{6}{|c|}{ Regression model with sub-models } \\
\hline & $(1)$ & $(2)$ & (3) & $(4)$ & (5) & (6) \\
\hline$T A$ & $8.72^{* * *}$ & $1.14^{* * *}$ & $1.13^{* * *}$ & $5.31^{\star * *}$ & $4.80^{* * *}$ & 3.14 \\
\hline$D$ & - & $-1.62^{* * *}$ & $-1.60^{* * *}$ & $-9.77^{\star * *}$ & $-9.84^{* * *}$ & $-1.01^{\star * *}$ \\
\hline$I T B$ & - & - & -3.57 & $-4.82^{*}$ & -3.16 & -6.75 \\
\hline NOI & - & - & - & $7.24^{\star * \star}$ & $5.24^{* *}$ & $6.49^{* *}$ \\
\hline$T L$ & - & - & - & - & - & - \\
\hline$N P A$ & - & - & - & - & - & - \\
\hline$L L P$ & - & - & - & - & - & - \\
\hline$B R$ & - & - & - & - & - & - \\
\hline$D P$ & - & - & - & - & - & - \\
\hline$T 1$ & - & - & - & - & - & - \\
\hline Constant & $0.82^{* * *}$ & $0.95^{\star * *}$ & $0.95^{\star * *}$ & $1.04^{\star * *}$ & $1.08^{\star * *}$ & $1.12^{\star * *}$ \\
\hline Obs & 293 & 276 & 276 & 211 & 211 & 210 \\
\hline R-squared & 0.298176 & 0.321316 & 0.323315 & 0.392770 & 0.408185 & 0.413889 \\
\hline $\mathrm{Nb}$ of Banks & 23 & 23 & 23 & 23 & 23 & 23 \\
\hline$H-\operatorname{stat}(p-$ value $)$ & 0.0178 & 0.0000 & 0.0000 & 0.0000 & 0.0000 & 0.0000 \\
\hline
\end{tabular}


towards a more stable system could be implemented. In order to restore the health of banks and revive lending, the central bank governor, Raghuram Rajan, whose terms ended on Sept 4, 2016, started a bank-by-bank review of stressed accounts. He assigned a deadline to public banks (end of March 2017) to have them clean up their balance sheet and enhance their provisions. However, many of national banks have previously met the Basel's III principal requirements (the target being 31, March, 2019).

The Indian banking sector is a two-tiered system. On one side, the banks with the lowest profits take the highest market share. On the other side, banks with highest levels of earnings face strong constraints in their activity. In Tables 10 and 11, unlike public banks, the level of significance of the net operating income of private banks is weak. Total assets are a significant variable in models 11 and 12. The amounts of loans distributed (models 9 to 12) however constitute a solid source of profits for these banks. These results could confirm the relevance of assumption 4 (section 2). Private banks suffer from limitations in their activities.

Table 9. State Banks, Part II

\begin{tabular}{|c|c|c|c|c|c|c|}
\hline \multirow{2}{*}{ Variable } & \multicolumn{6}{|c|}{ Regression model with sub-models } \\
\hline & $(7)$ & $(8)$ & $(9)$ & $(10)$ & $(11)$ & $(12)$ \\
\hline$T A$ & 1.66 & 5.24 & 2.19 & 2.27 & 2.31 & $3.49^{*}$ \\
\hline$D$ & $-9.55^{\star * *}$ & $-4.23^{\star *}$ & -3.32 & -3.36 & -3.36 & -2.67 \\
\hline$I T B$ & 61.13 & -1.04 & -2.95 & -2.90 & -2.34 & -7.78 \\
\hline NOI & $6.26^{\star *}$ & $1.24^{* * *}$ & $1.70^{* * *}$ & $1.72^{* * *}$ & $1.46^{* * *}$ & $1.06^{* * *}$ \\
\hline$T L$ & $3.27^{\star *}$ & 1.39 & 7.01 & 7.68 & 1.17 & 2.15 \\
\hline NPA & - & $-3.54^{\star * *}$ & $-2.52^{* * *}$ & $-2.46^{\star * *}$ & $-1.85^{\star \star \star}$ & $-2.90^{* * *}$ \\
\hline$L L P$ & - & - & $-0.23^{\star * *}$ & $-0.23^{\star * \star}$ & $-0.18^{\star \star \star}$ & $-0.38^{\star * *}$ \\
\hline$B R$ & - & - & - & 0.3 & 0.2 & 0.5 \\
\hline$D P$ & - & - & - & - & $-23.31^{\star * *}$ & -2.68 \\
\hline T1 & - & - & - & - & - & $3.80^{* *}$ \\
\hline Constant & $1.14^{* * *}$ & $0.97^{\star * *}$ & $1.31^{* * *}$ & $1.28^{* * *}$ & $1.31^{* * *}$ & $0.92^{* * *}$ \\
\hline Obs & 210 & 198 & 194 & 191 & 189 & 98 \\
\hline R-squared & 0.424458 & 0.569653 & 0.669880 & 0.672397 & 0.687682 & 0.860902 \\
\hline $\mathrm{Nb}$ of Banks & 23 & 23 & 23 & 22 & 22 & 19 \\
\hline$H-\operatorname{stat}(p$-value $)$ & 0.0000 & 0.0163 & 0.0031 & 0.0066 & 0.0083 & 0.3451 \\
\hline
\end{tabular}

Table 10. Private Banks, Part I

\begin{tabular}{|c|c|c|c|c|c|c|}
\hline \multirow{2}{*}{ Variable } & \multicolumn{6}{|c|}{ Regression model with sub-models } \\
\hline & $(1)$ & (2) & (3) & $(4)$ & (5) & (6) \\
\hline$T A$ & 9.76 & 1.34 & 2.55 & 1.10 & 6.19 & 8.38 \\
\hline$D$ & - & -2.15 & -3.33 & -1.44 & -1.09 & -5.11 \\
\hline ITB & - & - & -1.98 & -2.83 & -2.47 & -2.76 \\
\hline NOI & - & - & - & 7.45 & 6.84 & 6.20 \\
\hline$T L$ & - & - & - & - & - & - \\
\hline NPA & - & - & - & - & - & - \\
\hline$L L P$ & - & - & - & - & - & - \\
\hline$B R$ & - & - & - & - & - & - \\
\hline$D P$ & - & - & - & - & - & - \\
\hline$T 1$ & - & - & - & - & - & - \\
\hline Constant & $0.85^{\star * *}$ & $0.88^{\star * *}$ & $0.90^{\star * \star}$ & $1.07^{\star * *}$ & $1.07^{\star * *}$ & $1.06^{\star * *}$ \\
\hline Obs & 359 & 300 & 300 & 247 & 247 & 247 \\
\hline R-squared & 0.514768 & 0.512165 & 0.514442 & 0.678659 & 0.678952 & 0.679334 \\
\hline $\mathrm{Nb}$ of Banks & 29 & 27 & 27 & 27 & 27 & 27 \\
\hline$H-\operatorname{stat}(p$-value $)$ & 0.0914 & 0.1581 & 0.1154 & 0.0089 & 0.0160 & 0.0510 \\
\hline
\end{tabular}


Table 11. Private Banks, Part II

\begin{tabular}{|c|c|c|c|c|c|c|}
\hline \multirow{2}{*}{ Variable } & \multicolumn{6}{|c|}{ Regression model with sub-models } \\
\hline & (7) & (8) & (9) & $(10)$ & $(11)$ & (12) \\
\hline$T A$ & 6.35 & 5.37 & 8.39 & 8.55 & $1.26^{\star *}$ & $1.31^{\star *}$ \\
\hline$D$ & -1.16 & -7.45 & -7.58 & -6.98 & -6.62 & -3.09 \\
\hline$I T B$ & -2.57 & -4.22 & -4.60 & -9.91 & -6.32 & -8.25 \\
\hline NOI & 6.00 & $1.53^{*}$ & $2.30^{\star * *}$ & $2.39^{* * *}$ & $2.49^{* * *}$ & $2.15^{\star \star}$ \\
\hline$T L$ & 4.86 & 1.15 & $2.15^{\star \star *}$ & $2.09^{* *}$ & $2.12^{* * *}$ & $2.21^{\star \star *}$ \\
\hline NPA & - & $-1.11^{\star * *}$ & $-8.51^{* * *}$ & $-7.58^{\star *}$ & $-7.38^{\star *}$ & -4.01 \\
\hline$L L P$ & - & - & $-0.25^{\star * *}$ & $-0.25^{\star * *}$ & $-0.25^{\star * *}$ & $-0.39^{* * *}$ \\
\hline$B R$ & - & - & - & 0.385 & -0.1 & -0.4 \\
\hline$D P$ & - & - & - & - & $-233.37^{\star * *}$ & $-183.52^{\star *}$ \\
\hline T1 & - & - & - & - & - & 2.73 \\
\hline Constant & $1.08^{\star * \star}$ & $1.09^{\star * \star}$ & $1.49^{* * *}$ & $1.55^{\star * *}$ & $2.03^{* * *}$ & $1.26^{\star * *}$ \\
\hline Obs & 247 & 238 & 238 & 214 & 204 & 150 \\
\hline R-squared & 0.680519 & 0.708339 & 0.750245 & 0.738613 & 0.780221 & 0.849219 \\
\hline $\mathrm{Nb}$ of Banks & 27 & 27 & 25 & 23 & 22 & 20 \\
\hline$H-\operatorname{stat}(p-v a l u e)$ & 0.0071 & 0.0020 & 0.0000 & 0.0000 & 0.0000 & 0.0000 \\
\hline
\end{tabular}

Table 12. Mean Comparisons tests

\begin{tabular}{|l|c|c|c|c|c|c|}
\hline \multirow{2}{*}{} & \multicolumn{2}{|c|}{ ROA } & \multicolumn{2}{c|}{ NPA } & \multicolumn{2}{c|}{ NOI } \\
\cline { 2 - 7 } & Difference & t-stat & Difference & t-stat & Difference & t-stat \\
\hline State \& Foreign & 1.318 & 8.355 & 35657979.634 & 7.941 & 72779.171 & 2.757 \\
\hline Private \& Foreign & 1.077 & 6.173 & 35714467.967 & 6.895 & 91908.676 & 3.675 \\
\hline
\end{tabular}

A comparison (see also Table 5) with foreign banks (Table 12), shows that the differences in terms of ROA between the banks are important. The amounts separating the banks in terms of NOI are also considerable. These outcomes approve the work of Casu et al. (2013).

\section{Conclusions}

Public banks in India have long been perceived as the black sheep of the Indian banking sector, with low profitability ratios despite government support and large balance sheets (Ahamed, 2017). We investigated and compared the performance of Indian public banks versus private banks, to understand their specific potential strengths and weaknesses, and evaluate their ability to meet the challenge of offering banking services to the fast-growing world's largest unbanked population.

First, we found that the effectiveness of the India's banking segment rest on primarily on the ownership structure and the level of non-performing assets. In addition, our results allow us to state that public banks are not necessarily the weak performers. Similarly, private banks are not necessarily high performers. Moreover, our comparison analysis identifies possible factors for improving the effectiveness and sustainability of Indian banks. While the profitability of public banks could be enhanced by directing more attention to revenues from other revenue, the cost-effectiveness of private banks on the other hand is still constrained. Finally, the ability for both national and non state owned banks to keep pace with Indian banking needs will depend on their ability to deal with the level of non-performing assets (Das \& Das, 2005; Das \& Ghosh, 2006).

Beyond the existing regulatory constraints directed at cleaning up banks' balance sheets, further structural reforms are required, in particular to address the issues we highlight in our results. Straightforward recapitalization strategies to boost profitability ratios may not be sufficient in the long run. Similarly, privatizing the model pupils in the public banks cannot be considered a long-term viable alternative (ENS, 2017). Future reforms must consider the key role of public banks in the funding and the expansion of the India's economy, particularly when it comes to projects of social importance and national priority. Reforming requires a balanced approach targeted to both nationalized and other banks, if the challenge to bank the growing unbanked population is to be met.

When it comes to improving public banks profitability, a promising avenue highlighted in our results is the possibility to increase the use of their sizeable existing assets towards to grow non-interest income. Another possibility lies with Net Interest Margins (NIM). India's average NIM was approximately $3.1 \%$ in 2014 , while at the same time it was $3.6 \%$ in the United States and $2.9 \%$ in China 
(Ghosh, 2015). Allowing more flexibility to the banks will help them enhance these margins. Finally, easing the constraints on private and foreign banks in the country is likely to foster synergies going forward. As we can see, growth of the India's banking segment, creating the conditions for a more balanced, sound and profitable banking system is the first step in charting the path for sustained economic growth. This entails better competition between the banks and safer investments.

\section{Author contributions}

The authors contributed equally.

\section{Disclosure statement}

The authors do not have any conflict of interest.

\section{References}

Ahamed, M. M. (2017). Asset quality, non-interest income, and bank profitability: Evidence from Indian banks. Economic Modelling, 63, 1-14.

https://doi.org/10.1016/j.econmod.2017.01.016

Altman, E. I., \& Sabato, G. (2005). Modeling credit risk for SMEs: Evidence from the US market. Managing and measuring risk: emerging global standards and regulations after the financial crisis. Abacus, 43, 332-357.

https://doi.org/10.1142/9789814417501_0009

Altman, E. I., Rijken, H., Watt, M., Balan, D., Forero, J., \& Mina, J. (2010). The Z-Metrics ${ }^{\mathrm{Tx}}$ methodology for estimating company credit ratings and default risk probabilities (pp. 1821). RiskMetrics Group.

Ammar, N., \& Boughrara, A. (2019). The impact of revenue diversification on bank profitability and risk: evidence from MENA banking industry. Macroeconomics and Finance in Emerging Market Economies, 12(1), 36-70.

https://doi.org/10.1080/17520843.2018.1535513

Banerjee, S., \& Velamuri, M. (2015). The conundrum of profitability versus soundness for banks by ownership type: Evidence from the Indian banking sector. Review of Financial Economics, 26(1), 12-24. https://doi.org/10.1016/j.rfe.2015.04.001

Bawa, J. K., Goyal, V., Mitra, S. K., \& Basu, S. (2019). An analysis of NPAs of Indian banks: Using a comprehensive framework of 31 financial ratios. IIMB Management Review, 31(1), 5162. https://doi.org/10.1016/j.iimb.2018.08.004

Bhaumik, S. K., \& Dimova, R. (2004). How important is ownership in a market with level playing field?: The Indian banking sector revisited. Journal of Comparative Economics, 32(1), 165-180. https://doi.org/10.1016/j.jce.2003.12.001

Bhaumik, S. K., \& Piesse, J. (2008). Does lending behaviour of banks in emerging economies vary by ownership? Evidence from the Indian banking sector. Economic Systems, 32(2), 177-196. https://doi.org/10.1016/j.ecosys.2007.04.004

Bongini, P., Cucinelli, D., Battista, M. L., \& Nieri, L. (2019). Profitability shocks and recovery in time of crisis evidence from European banks. Finance Research Letters, 30, 233-239. https://doi.org/10.1016/j.frl.2018.10.003

Casu, B., Ferrari, A., \& Zhao, T. (2013). Regulatory reform and productivity change in Indian banking. Review of Economics and Statistics, 95(3), 1066-1077.

https://doi.org/10.1162/REST_a_00298
Chen, Z., Li, K., \& He, L.-Y. (2019). Has internet finance decreased the profitability of commercial banks?: evidence from China. Emerging Markets Finance and Trade, 56(13), 30153032. https://doi.org/10.1080/1540496X.2019.1624159

Cruz-García, P., Forte, A., \& Peiró-Palomino, J. (2020). On the drivers of profitability in the banking industry in restructuring times: a Bayesian perspective. Applied Economic Analysis, 28(83), 111-131. https://doi.org/10.1108/AEA-01-2020-0003

Das, A., \& Das, S. (2007). Scale economies, cost complementarities and technical progress in Indian banking: evidence from fourier flexible functional form. Applied Economics, 39(5), 565-580. https://doi.org/10.1080/00036840500428138

Das, A., \& Ghosh, S. (2006). Financial deregulation and efficiency: An empirical analysis of Indian banks during the post reform period. Review of Financial Economics, 15(3), 193-221. https://doi.org/10.1016/j.rfe.2005.06.002

Das, A., \& Kumbhakar, S. C. (2012). Productivity and efficiency dynamics in Indian banking: An input distance function approach incorporating quality of inputs and outputs. Journal of Applied Econometrics, 27(2), 205-234.

https://doi.org/10.1002/jae.1183

ENS. (2017). Privatise viable PSBS, make non-viables narrow banks. In The Indian Express.

Fujii, H., Managi, S., \& Matousek, R. (2014). Indian bank efficiency and productivity changes with undesirable outputs: a disaggregated approach. Journal of Banking \& Finance, 38, 41-50. https://doi.org/10.1016/j.jbankfin.2013.09.022

Ghosh, S. (2015). Chastising public sector banks for every failure is a comedy of errors. The Economic Times. https://doi.org/10.1093/acprof:oso/9780199458943.001.0001

Gulati, R., \& Kumar, S. (2016). Assessing the impact of the global financial crisis on the profit efficiency of Indian banks. Economic Modelling, 58, 167-181.

https://doi.org/10.1016/j.econmod.2016.05.029

Jayaraman, A. R., \& Srinivasan, M. R. (2014). Analyzing profit efficiency of banks in India with undesirable output - Nerlovian profit indicator approach. IIMB Management Review, 26(4), 222-233. https://doi.org/10.1016/j.iimb.2014.09.003

Kapoor, A. (2014). Financial inclusion and the future of the Indian economy. Futures, 56, 35-42. https://doi.org/10.1016/j.futures.2013.10.007

KPMG-CII. (2013). Maneuvering through turbulence: Emerging strategies. KPMG.

Kumbhakar, S., \& Sarkar, S. (2005). Theory and application of productivity and efficiency, econometric and DEA approach. Macmillan.

Mueller, D. C. (1977). The persistence of profits above the norm. Economica, 44(176), 369-380. https://doi.org/10.2307/2553570

Narasimham, M., Ghosh, A., Golporia, M. N., Nadkarnl, S. S., Vaghul, N., Shroff, M. R., \& Reddy, K. J. (1991). Report of the Committee on the Financial System. RBI.

Park, K. H., \& Weber, W. L. (2006). A note on efficiency and productivity growth in the Korean banking industry, 1992-2002. Journal of Banking \& Finance, 30(8), 2371-2386. https://doi.org/10.1016/j.jbankfin.2005.09.013

Patti, E. B., \& Hardy, D. C. (2005). Financial sector liberalization, bank privatization, and efficiency: Evidence from Pakistan. Journal of Banking \& Finance, 29(8-9), 2381-2406. https://doi.org/10.1016/j.jbankfin.2005.03.019

Pennathur, A. K., Subrahmanyam, V., \& Vishwasrao, S. (2012). Income diversification and risk: Does ownership matter? An empirical examination of Indian banks. Journal of Banking \& Finance, 36(8), 2203-2215. https://doi.org/10.1016/j.jbankfin.2012.03.021 
Prasad, A., \& Ghosh, S. (2005). Competition in Indian banking. IMF Working Paper No. 05/141. https://doi.org/10.5089/9781451861600.001

Ray, S. C., \& Das, A. (2010). Distribution of cost and profit efficiency: Evidence from Indian banking. European Journal of Operational Research, 201(1), 297-307. https://doi.org/10.1016/j.ejor.2009.02.030

Sahoo, B. K., \& Tone, K. (2009). Decomposing capacity utilization in data envelopment analysis: An application to banks in India. European Journal of Operational Research, 195(2), 575-594. https://doi.org/10.1016/j.ejor.2008.02.017

Sarkar, J., \& Bhaumik, S. K. (1998). Deregulation and the limits to banking market competition: some insights from India. International Journal of Development Banking, 16(2), 29-42.

Sarkar, J., Sarkar, S., \& Bhaumik, S. K. (1998). Does ownership always matter? - Evidence from the Indian banking industry. Journal of Comparative Economics, 26(2), 262-281. https://doi.org/10.1006/jcec.1998.1516

Sathye, M. (2003). Efficiency of banks in a developing economy: The case of India. European Journal of Operational Research, 148(3), 662-671.

https://doi.org/10.1016/S0377-2217(02)00471-X
Sensarma, R. (2008). Deregulation, ownership and profit performance of banks: evidence from India. Applied Financial Economics, 18(19), 1581-1595.

https://doi.org/10.1080/09603100701720385

Tabak, B. M., \& Tecles, P. L. (2010). Estimating a Bayesian stochastic frontier for the Indian banking system. International Journal of Production Economics, 125(1), 96-110. https://doi.org/10.1016/j.ijpe.2010.01.008

Tamatam, R., Dutta, P., Dutta, G., \& Lessmann, S. (2019). Efficiency analysis of Indian banking industry over the period 2008-2017 using data envelopment analysis. Benchmarking: An International Journal, 26(8), 2417-2442. https://doi.org/10.1108/BIJ-12-2018-0422

Vera-Gilces, P., Camino-Mogro, S., Ordeñana-Rodríguez, X., \& Cornejo-Marcos, G. (2020). A look inside banking profitability: Evidence from a dollarized emerging country. The Quarterly Review of Economics and Finance, 75, 147-166. https://doi.org/10.1016/j.qref.2019.05.002

Zhao, T., Casu, B., \& Ferrari, A. (2010). The impact of regulatory reforms on cost structure, ownership and competition in Indian banking. Journal of Banking \& Finance, 34(1), 246-254. https://doi.org/10.1016/j.jbankfin.2009.07.022 